An Introduction to the Blood-Brain Barrier 


\section{An Introduction to the Blood-Brain Barrier}

\section{Hugh Davson}

Emeritus Professor,

Sherrington School of Physiology UMDS,

Guy's and St Thomas's Hospitals, London

Berislav Zloković

Associate Professor of Neurosurgery,

Physiology and Biophysics,

USC School of Medicine, Los Angeles

\section{Ljubisa Rakić}

Professor of Neurobiology and Biochemistry,

School of Medicine, Belgrade

and

\section{Malcolm B. Segal}

Reader in Physiology,

Sherrington School of Physiology UMDS,

Guy's and St Thomas's Hospitals, London

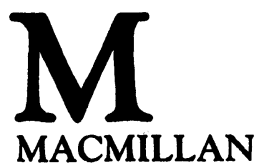


(c) The authors 1993

Softcover reprint of the hardcover 1st edition 1993

All rights reserved. No reproduction, copy or transmission of this publication may be made without written permission.

No paragraph of this publication may be reproduced, copied or transmitted save with written permission or in accordance with the provisions of the Copyright, Designs and Patents Act 1988, or under the terms of any licence permitting limited copying issued by the Copyright Licensing Agency, 90 Tottenham Court Road, London W1P 9HE.

Any person who does any unauthorised act in relation to this publication may be liable to criminal prosecution and civil claims for damages.

First published 1993 by

THE MACMILLAN PRESS LTD

Houndmills, Basingstoke, Hampshire RG21 2XS

and London

Companies and representatives

throughout the world

ISBN 978-1-349-11884-7 ISBN 978-1-349-11882-3 (eBook)

DOI 10.1007/978-1-349-11882-3

A catalogue record for this book is available

from the British Library.

Typeset by Wearset

Boldon, Tyne and Wear 


\section{Contents}

$\begin{array}{lll}\text { Preface } & \text { vii }\end{array}$

1. History and basic concepts 1

Classical experiments 1

The extracellular space of the brain 3

The cerebrospinal fluid 4

Permeability of the blood-brain barrier 11

Permeability: definition and measurement 14

Michaelis-Menten kinetics $\quad 23$

Active transport $\quad 40$

Application to the blood-brain barrier $\quad 56$

The cerebrospinal fluid and the blood-CSF barrier $\quad 80$

Transposition to the blood-brain barrier 101

Enzymatic contributions to the blood-brain barrier 109

Breakdown of the blood-brain barrier $\quad 110$

Penetration of carrier-bound hormones $\quad 112$

Penetration of large molecules $\quad 114$

The broken-down barrier $\quad 121$

Steady-state CSF concentrations $\quad 126$

Complete morphology of the blood-brain barrier $\quad 128$

2. Transport of glucose and amino acids in the central nervous system $\quad 146$

Glucose $\quad 146$

Amino acids 170

3. Peptides and proteins 195

Peptides in the central nervous system $\quad 195$

Functions of peptides in the brain 201

Peptide and protein interactions at the blood-brain barrier 218

Regulation of protein transport 242

Modulation of peptide transport 243

Enzymatic degradation of peptides $\quad 244$

Peptide receptors in non-barrier regions 245

Therapeutic applications 249

Peptides and proteins in the CSF 253

4. Transport of some precursors of nucleotides and some vitamins

Nucleotide precursors $\quad 273$

Vitamins 285 
5. Experimental models in the study of the pathology of the blood-brain barrier

Introduction

Amphetamine experimental psychosis

Experimental allergic encephalomyelitis

Cortical lesions 


\section{Preface}

The possibility of producing a short introduction to the physiology of the blood-brain barrier was both discussed and agreed by the authors after a small symposium on the subject had been held at the Serbian Academy of Arts and Science in 1989. The present volume is the result; in it we have tried to present lucidly the physical factors governing transport from blood into the central nervous tissue and the cerebrospinal fluid, and then to describe some studies on specific aspects, notably the transport of amino acids, sugars and peptides. Finally, in view of the suspicion that some neurological diseases have as their basis a failure or impairment of the blood-brain barrier, we have included an account of some attempts to establish animal preparations that might serve as experimental models mimicking human pathology. If the reading of this book stimulates research on the pathology of some central nervous diseases, it will have achieved its main purpose; in addition, we trust that workers in the life sciences will find it a useful introduction to a field that has expanded explosively since the early prejudices against the concept of a blood-brain barrier were dispelled. We must conclude by thanking the Wellcome Trust, the British Council and the Federal Yugoslav Zavod for their financial help in promoting the co-operation between workers in Britain and Yugoslavia that has culminated in the writing of this book. 